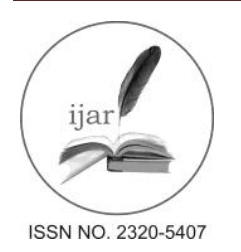

\author{
Journal homepage: http://www.journalijar.com

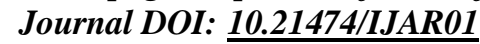

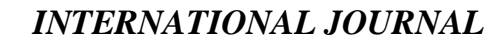

OF ADVANCED RESEARCH

RESEARCH ARTICLE

\title{
INDOLE-3-ACETIC ACID PRODUCTION AND ENHANCED PLANT GROWTH PROMOTION OF VIGNA UNGUICULATA (L).WALP BY AZOTOBACTER SP.
}

\author{
B.Sivasankari*, Anandharaj.M. \\ Department of Biology, Gandhigram Rural Institute- Deemed University, Gandhigram-624 302 Dindigul (Dt), \\ Tamilnadu, India.
}

\section{Manuscript Info}

Manuscript History:

Received: 18 March 2016

Final Accepted: 26 April 2016

Published Online: May 2016

Key words:

Azotobacter, Indole acetic acid, vigna unguiculata.

*Corresponding Author

B.Sivasankari.

\begin{abstract}
In the present study the rhizosphere soil sample was collected from different cultivation lands in and around Gandhigram Rural Institute- Deemed University, Gandhigram, Dindigul, Tamilnadu, India. Then the Azotobacter sp. Was isolated and identified using standard procedures. The Azotobacter sp. Was screened for Indole acetic acid production and standardized for IAA production at different tryptophan concentration i.e $1-5 \mathrm{mg} / \mathrm{ml}$ and control (without Tryptophan). The results showed that the Azotobacter sp. Significantly produce higher quantity of IAA $(52.80 \mathrm{mg} / \mathrm{ml})$ at $5 \mathrm{mg} / \mathrm{ml} \mathrm{of}$ tryptophan concentration on fifteenth day compared with others. A low amount $(7.48 \mathrm{mg} / \mathrm{ml})$ of IAA production was recorded by Azotobacter sp. In control (without tryptophan addition). The plant growth studies using Azotobacter sp. At different concentration $(0-5 \mathrm{ml})$ using vigna unguiculata (L).walp at different day intervals (5 and 10 days) were done. At tenth day the germination percentage (80\%), Root length (12.03 \pm 0.63$)$, Shoot length(24.68 \pm 0.43$)$, fresh weight of whole plant $(3.59 \pm 0.06)$ and dry weight of whole plant $(0.49 \pm 0.39)$ were significantly enhanced by the Azotobacter sp. at $5 \mathrm{ml}$ concentration on tenth day compared to other concentration and control.
\end{abstract}

Copy Right,IJAR, 2016, All rights reserved...

\section{Introduction:-}

Nowadays, under the modern agricultural practices, chemical fertilizers are used to boost the crop production. But the application of chemical fertilizers affects the total productivity of the crops and in the long run the soil becomes sterile and unfit for cultivation practices. Hence in order to enhance the fertility status of the soil, the natural way of feeding the soil with different types of organic inputs (composts, vermicomposts, Biofertilizers, farmyard manure etc.) has been developed so as to ensure sustained productivity ${ }^{1}$ Plant growth promoting rhizobacteria (PGPR) are considered to promote plant growth directly or indirectly. PGPR can exhibit a variety of characteristics responsible for influencing plant growth. The common traits include production of plant growth regulators (auxin, gibberellin, ethylene etc.), siderophores, $\mathrm{HCN}$ and antibiotics ${ }^{2}$. Indole acetic acid (IAA) is one of the most physiologically active auxins. IAA is a common product of L-tryptophan metabolism by several microorganisms including PGPR ${ }^{3,4}$. Microorganisms inhabiting rhizospheres of various plants are likely to synthesize and release auxin as secondary metabolites because of the rich supplies of substrates exuded from the roots compared with non rhizospheric soils. Plant morphogenic effects may also be a result of different ratios of plant hormones produced by roots as well as by rhizosphere bacteria. Diverse soil microorganisms including bacteria, fungi and algae are capable of producing physiologically active quantities of auxins, which may exert pronounced effects on plant growth and establishment ${ }^{5}$. 
Azotobacter spp. are free-living aerobic bacteria dominantly found in soils. They are non-symbiotic heterotrophic bacteria capable of fixing an average $20 \mathrm{~kg} \mathrm{~N} / \mathrm{ha} /$ per year. Besides, it also produces growth promoting substances and are shown to be antagonistic to pathogens. Azotobacter spp. are found in the soil and rhizosphere of many plants and their population ranges from negligible to $104 \mathrm{~g}-1$ of soil depending upon the physico-chemical and microbiological (microbial interactions) properties. Azotobacter chroococcum is the most prevalent species found but other species described include A.agilis, A.vinelandii, A. beijerinckii, A.insignis, A.macrocytogenes and A.paspali ${ }^{6}$. The inoculation of beneficial microorganisms into the soil to improve plant growth and productivity is called Biofertilizers. Research during the past few decades has led to the identification of certain biological organisms and their products that could potentially be used as fertilizer sources. This strategy of fertilizing the soil with biological sources has been widely accepted and recognized as a viable alternative to the application of chemical fertilizers. Nitrogen fixing bacteria may be important for plant nutrition by increasing nitrogen uptake by the plants, and playing a significant role as plant growth promoting bacteria in the biofertilization of crops ${ }^{7}$.Several authors have shown the beneficial effects of Azotobacter chroococcum on vegetative growth and yields of maize, as well as the positive effect of inoculation with this bacterium on wheat. Recently, it has been also shown that strains of Azotobacter could be usefully employed both in aquaculture systems ${ }^{8}$ and in vermicompost production ${ }^{9}$, due to their ability of fixing nitrogen and solubilizing phosphates. An additional reason which justifies the interest on these micro-organisms is that the species Azotobacter vinelandii and A. chroococcum produce exopolysaccharides with high potential value related to their wide range of commercial applications ${ }^{10}$. The aim of the present study was to isolate, identify, asses the IAA synthesis and plant growth promotion of vigna unguiculata (L).walp by Azotobacter sp.

\section{Materials and Methods:- \\ Collection of Soil sample:-}

soil samples were collected from different cultivated lands in and around Gandhigram Rural Institute-Deemed University, Gandhigram, Dindigul (Dt), Tamilnadu. Samples were taken at a depth of 10-15 cm below the surface of soil in to the sterile polythene bags and immediately transferred into the laboratory.

\section{Isolation of Azotobacter sp:-}

Azotobacter sp. was isolated from the soil using nitrogen free Jensen's medium (sucrose 20 g, Dipotassium hydrogen phosphate $1 \mathrm{~g}$, magnesium sulfate $0.5 \mathrm{~g}$, sodium chloride $0.5 \mathrm{~g}$, ferrous sulfate $0.1 \mathrm{~g}$, sodium molybdate $0.005 \mathrm{~g}$, agar $20 \mathrm{~g}$, for 1 liter, $\mathrm{pH} 6.9)^{5}$. Isolates of Azotobacter sp. were biochemically identified using Gram reaction, $\mathrm{H}_{2} \mathrm{~S}$ production, starch hydrolysis, carbohydrate fermentation, IMVIC tests, and oxidase test as per the standard methods ${ }^{11}$. Isolated and identified Azotobacter strains were pure cultured using the jensen's medium.

\section{Screening of indole acetic acid production by Azotobacter sp:-}

All the Azotobacter sp. strains were screened for the production of IAA. Azotobacter sp. were separately inoculated in the Jensen's broth medium with tryptophan $(1 \mathrm{mg} / \mathrm{ml})$ and incubated at $28 \pm 2{ }^{\circ} \mathrm{C}$ for one week. After a week the cultures were centrifuged at $3000 \mathrm{rpm}$ for $30 \mathrm{~min}$. Two milliliters of the supernatant was mixed with 2 drops of orthophosphoric acid and $4 \mathrm{ml}$ of Salkowaski's reagent $(50 \mathrm{ml}, 35 \%$ perchloric acid $+1 \mathrm{ml} 0.5 \mathrm{FeCl} 3)$. Development of a pink colour indicates IAA production. O.D. was read at $530 \mathrm{~nm}$ using Spectronic 200. Every 5 days after incubation the amount of IAA produced by the test organism was estimated. The level of IAA produced was estimated by a standard IAA graph.

\section{Standardization of tryptophan concentration and incubation periods required for IAA production by Azotobacter sp:-}

The Azotobacter sp. was inoculated in jensen's broth containing five different concentration of tryptophan i.e. 1 to 5 $\mathrm{mg} / \mathrm{ml}$. the rate of production of IAA was estimated once in five days for fifteen days. After incubation the amount of IAA was measured by above method.

\section{Preparation of standard graph of IAA:-}

Different concentrations of IAA was prepared ranging from $10 \mathrm{microgram} / \mathrm{ml}$ to $100 \mathrm{micrograms} / \mathrm{ml}$. To each $1 \mathrm{ml}$ of the standard IAA , 2ml Salkowaski reagent is added and incubated for 25 minutes in the dark and readings were taken at $530 \mathrm{~nm}$ by Spectronic 200. Standard graph was prepared by plotting concentration of IAA in micrograms/ml Vs Optical Density at $530 \mathrm{~nm}^{12}$. 


\section{Evaluation of plant growth using Azotobacter sp:-}

The Azotobacter sp. was tested for plant growth activity at 5 different concentrations i.e. 1, 2, 3, 4 and $5 \mathrm{ml}$ at two different day intervals (5 and 10 days) with proper control. The seeds of Vigna unguiculata (cow pea) was surface sterilized with $0.1 \%$ mercuric chloride and sown in cups containing sterilized vermiculite and all the cups were regularly watered and germination and plant growth were observed for 10 days. Growth parameter such as germination percentage, shoot length, root length, fresh weight of the whole plant and dry weight of the whole plant were measured using standard procedure. All cups were placed in the illuminated chamber at 1500 lux.

\section{Germination Percentage:-}

The germination percentages of $\mathrm{V}$. unguiculata seeds in control and in various treatments were calculated by counting the germination seeds out of 10 seeds sown in the respective potting medium.

Germination Percentage $=$

No. of seeds germinated

Shoot length:-

Total no. of seeds sown

$\times 100$

The shoot length was measured from the ground to the growing point on the 5 and 10 days after sowing and the average shoot length is expressed in centimeter for each treatment and control.

\section{Root length:-}

The length of root was measured from a fixed point just below the surface of the soil to the end of the root on the 5 and 10 days after sowing and the average shoot length is expressed in centimeter for each treatment and control.

\section{Fresh weight of the whole plant:-}

On the 5 and 10 day the plants were carefully removed from the respective cups, gently washed with water, blotted and weighted separately for each treatment and the control. The average fresh weight is expressed in grams.

\section{Dry weight of the whole plant:-}

After measuring the fresh weight, the plants were dried in hot air oven at $70^{\circ} \mathrm{C}$ to constant weight and then weighed. The average dry weight of the plants on the 5 and 10 days is expressed in grams for each treatment and the control.

\section{Statistical Analysis:-}

The following statistical tools were used for the analysis and interpretation of the data. The experimental results are presented in the form of tables using Microsoft Excel (version 2007). Mean and standard Deviation were also calculated with the help of the same tool.

\section{Results and discussions:-}

Azotobacter isolated from rhizospheric soils were tentatively identified on the basis of biochemical tests and sugar fermentation behavior as described in Bergey's manual of determinative bacteriology. These bacterial isolates were screened for their ability to produce plant growth regulator, IAA. Varying levels of IAA production were recorded with different concentrations of tryptophan i.e. $0,1,2,3,4$ and $5 \mathrm{mg} / \mathrm{ml}$ (Table 1).

The range of IAA production by Azotobacter isolates in control (without tryptophan) was (4.49-7.48 $\mu \mathrm{g} / \mathrm{ml}$ ). A significant increase in the production of IAA was recorded at $5 \mathrm{mg} / \mathrm{ml}$ of tryptophan was $(52.80 \mu \mathrm{g} / \mathrm{ml})$ on fifteenth day compared to $1 \mathrm{mg} / \mathrm{ml}(14.62), 2 \mathrm{mg} / \mathrm{ml}(22.45), 3 \mathrm{mg} / \mathrm{ml}(32.41)$ and $4 \mathrm{mg} / \mathrm{ml}(41.39)$. The range of IAA production on fifth day was $8.05-24.40 \mathrm{mg} / \mathrm{ml}$ and tenth day is $11.84-39.63 \mathrm{mg} / \mathrm{ml}$.

Same kind of work was done by Vikram patil in 2011 he has observed the production of IAA by Azotobacter sp. without tryptophan in the range of 2.68 to $10.80 \mathrm{mg} / \mathrm{ml}$. Higher amount of IAA production was observed (32.80 $\mathrm{mg} / \mathrm{ml}$ ) on medium supplemented with $5 \mathrm{mg} / \mathrm{ml}$ after 15 day incubation ${ }^{11}$.

Farah ahmed et al, 2005 observed Pseudomonas isolates were able to produce IAA without tryptophan in the range 5.34 to $22.4 \mathrm{mg} / \mathrm{ml}$. and higher amount of IAA production was observed at $5 \mathrm{mg} / \mathrm{ml}$ concentration of tryptophan was $52.8 \mathrm{mg} / \mathrm{ml}$ after 7 days of incubation ${ }^{13}$. 
Evaluation of plant growth activity by Azotobacter sp:-

Highest germination percentage was observed in plants treated with $5 \mathrm{ml}$ concentration of Azotobacter culture on tenth day compared to others and control the results are given in figure 1.The shoot length (24.68 \pm 0.43$)$, root

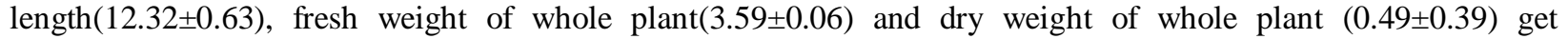
significantly increased at $5 \mathrm{ml}$ concentration on tenth day compared to shoot length (24.02 \pm 0.47$)$, root length(11.32 \pm 0.68$)$, fresh weight of whole plant $(2.95 \pm 0.14)$ and dry weight of whole plant $(0.41 \pm 0.27)$ at $5 \mathrm{ml}$ concentration on fifth day and in the control.

The average root, shoot ratio was higher in B.subtilis treated yam minisetts in comparison to those not treated with the bacterial culture ${ }^{14}$. In earlier reports, root elongation was found to occur in Sesbania aculeate by inoculation with Azotobacter sp and Pseudomonas sp. ${ }^{15}$ in Vigna radiate by Pseudomonas putida ${ }^{16}$

The findings of the present investigation highlighted that IAA producing bacteria from local soil could be easily isolated and may be exploited after strain improvement for local use. However, further studies using IAA mutant strains of these isolates are needed to explore the exact contribution of IAA production in the promotion of plant growth as well as the contribution of other PGP traits. There are numerous soil microflora involved in the synthesis of auxins in pure culture and soil ${ }^{17}$. Some microorganisms produce auxins in the presence of a suitable precursor such as L-tryptophan. The effects of auxins on plant seedlings are concentration dependent, i.e. low concentration may stimulate growth while high concentrations may be inhibitory ${ }^{2}$.

Different plant seedlings respond differently to variable auxin concentrations ${ }^{18}$ and type of microorganisms. Substances produced by bacteria are released continuously and especially when they are produced on the surface of the plant root. The plant growth substances produced by Azotobacter improve plant growth by their direct effects on metabolic processes. However, they include proliferation of lateral roots and root hairs and thus increase nutrient absorption thereby it induce the plant growth ${ }^{19}$.

Table 1:- Amount of IAA produced by Azotobacter sp at different days of incubation

\begin{tabular}{|c|c|c|c|c|}
\hline S.No & $\begin{array}{c}\text { Tryptophan Concentration } \\
\mathbf{M g} / \mathbf{m l}\end{array}$ & \multicolumn{3}{|c|}{ IAA production at different days interval } \\
\cline { 3 - 5 } & Control & $\begin{array}{c}\mathbf{5} \mathbf{~ D a y} \\
\boldsymbol{\mu g} / \mathbf{m l}\end{array}$ & $\begin{array}{c}\mathbf{1 0} \mathbf{D a y} \\
\boldsymbol{\mu g} / \mathbf{m l}\end{array}$ & $\begin{array}{c}\mathbf{1 5} \mathbf{D a y} \\
\boldsymbol{\mu g} / \mathbf{m l}\end{array}$ \\
\hline 1 & 1 & 4.49 & 5.29 & 7.48 \\
\hline 2 & 2 & 8.05 & 11.84 & 14.62 \\
\hline 3 & 3 & 11.53 & 15.80 & 22.45 \\
\hline 4 & 4 & 18.26 & 21.60 & 32.41 \\
\hline 5 & 5 & 19.18 & 24.81 & 41.39 \\
\hline 6 & 24.40 & 39.63 & 52.80 \\
\hline
\end{tabular}

Table 2:- In vitro effect of Azotobacter sp (Culture broth) on growth of Vigna unguiculata (cow pea) after five days.

\begin{tabular}{|c|c|c|c|c|c|}
\hline \multirow{2}{*}{ S.No } & Concentration & \multicolumn{4}{|c|}{ Plant growth parameter } \\
\cline { 3 - 6 } & & Root Length $(\mathbf{c m})$ & Shoot Length $(\mathbf{c m})$ & Fresh Weight (gm) & Dry Weight (gm) \\
\hline 1 & Control & $6.23 \pm 0.12$ & $16.24 \pm 0.26$ & $1.39 \pm 0.13$ & $0.16 \pm 0.01$ \\
\hline 2 & $1 \mathrm{ml}$ & $10.07 \pm 0.20$ & $22.16 \pm 0.72$ & $1.42 \pm 0.19$ & $0.18 \pm 0.04$ \\
\hline 3 & $2 \mathrm{ml}$ & $10.00 \pm 0.83$ & $21.32 \pm 0.36$ & $1.48 \pm 0.08$ & $0.20 \pm 0.07$ \\
\hline 4 & $3 \mathrm{ml}$ & $09.83 \pm 0.04$ & $23.62 \pm 0.82$ & $2.68 \pm 0.05$ & $0.24 \pm 0.18$ \\
\hline 5 & $4 \mathrm{ml}$ & $10.86 \pm 0.50$ & $23.87 \pm 0.19$ & $2.73 \pm 0.03$ & $0.31 \pm 0.19$ \\
\hline 6 & $5 \mathrm{ml}$ & $11.32 \pm 0.68$ & $24.02 \pm 0.47$ & $2.95 \pm 0.14$ & $0.41 \pm 0.27$ \\
\hline
\end{tabular}

Values are presented as mean \pm standard deviation 
Table 3:- In vitro effect of Azotobacter sp (Culture broth) on growth of Vigna unguiculata (cow pea) after ten days.

\begin{tabular}{|c|c|c|c|c|c|}
\hline \multirow{2}{*}{ S.No } & \multirow{2}{*}{ Concentration } & \multicolumn{4}{|c|}{ Plant growth parameter } \\
\cline { 2 - 5 } & Control & $\begin{array}{c}\text { Root Length } \\
(\mathbf{c m})\end{array}$ & $\begin{array}{c}\text { Shoot Length } \\
(\mathbf{c m})\end{array}$ & $\begin{array}{c}\text { Fresh Weight } \\
(\mathbf{g m})\end{array}$ & $\begin{array}{c}\text { Dry Weight } \\
(\mathbf{g m})\end{array}$ \\
\hline 1 & $1 \mathrm{ml}$ & $10.80 \pm 0.23$ & $17.76 \pm 0.76$ & $1.38 \pm 0.18$ & $0.17 \pm 0.01$ \\
\hline 2 & $2 \mathrm{ml}$ & $11.04 \pm 0.70$ & $23.95 \pm 0.05$ & $1.43 \pm 0.15$ & $0.19 \pm 0.06$ \\
\hline 3 & $3 \mathrm{ml}$ & $11.06 \pm 0.15$ & $24.16 \pm 0.09$ & $2.51 \pm 0.23$ & $0.20 \pm 0.09$ \\
\hline 4 & $4 \mathrm{ml}$ & $11.12 \pm 0.04$ & $24.37 \pm 0.13$ & $2.64 \pm 0.05$ & $0.36 \pm 0.22$ \\
\hline 5 & $5 \mathrm{ml}$ & $12.03 \pm 0.63$ & $24.68 \pm 0.43$ & $3.59 \pm 0.06$ & $0.38 \pm 0.18$ \\
\hline 6 & & & & $0.49 \pm 0.39$ \\
\hline
\end{tabular}

Values are presented as mean \pm standard deviation

Figure 1:- Determination of seed germination percentage.

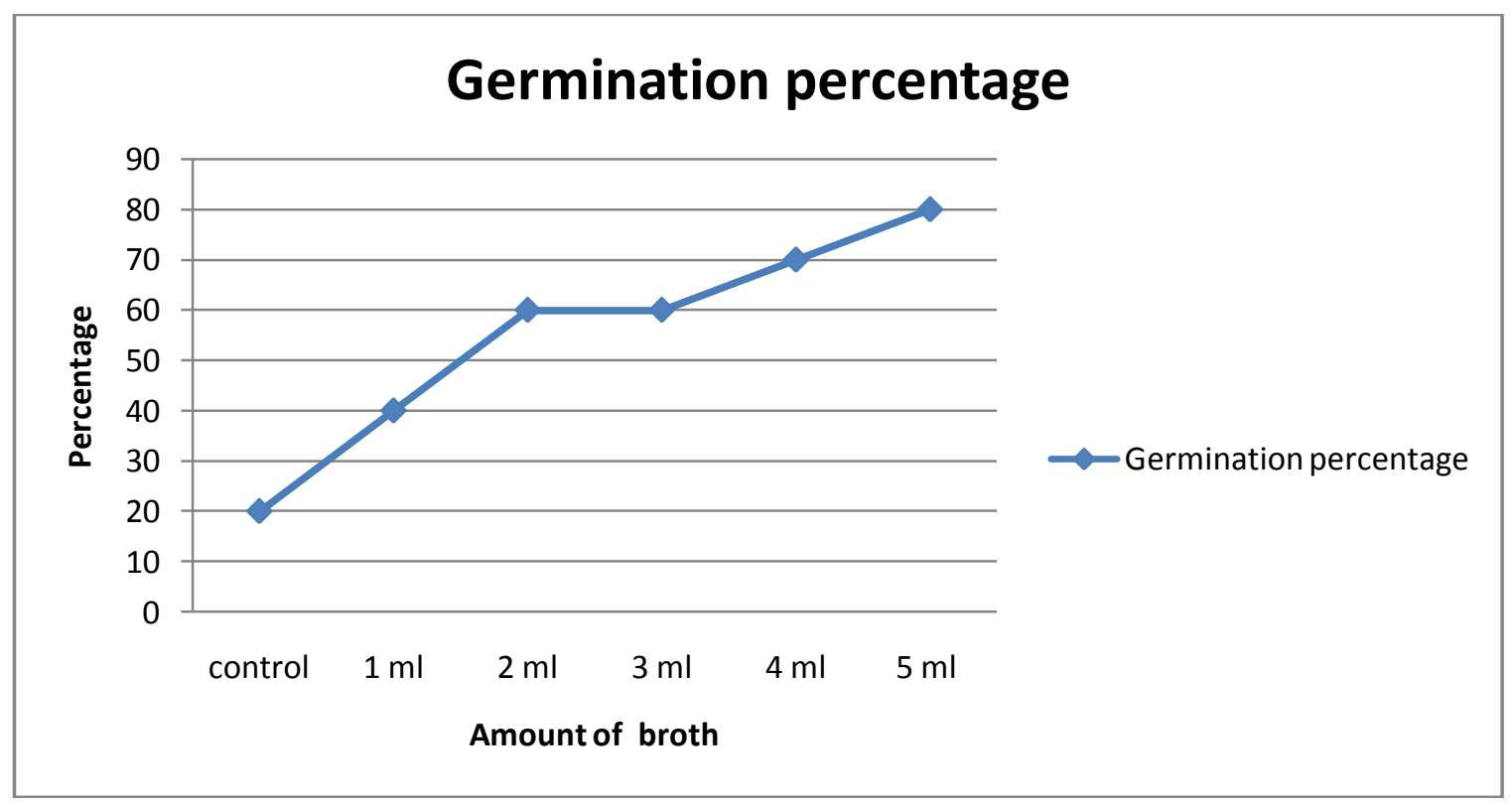

\section{Conclusion:-}

Inoculation of Azotobacter sp. in the plant growth medium enhanced various physiological activities culminating in higher biomass production in V.unguiculata. Since this is a non-hazardous way of fertilization of crop plants, it is very relevant to a developing country like India. This technique can save the farmers of India from the problem posed by high cost of fertilization by offering a comparatively inexpensive alternative Biofertilizers, while additionally preventing the degradation of the soil and thereby ensuring sustainable agriculture. 


\section{References:-}

1. Bhawalkar, U.S. 1996. Vermiculture Ecotechnology, Second Edition. Earthworm research Institute, Pune. Pp. 280.

2. Arshad M, Frankenberger WT Jr. Microbial production of plant growth regulators. In: Soil Microbial Ecol. Ed. Metting FB Jr, Marcel Dekker Inc., New York. 1992. pp 307-347.

3. Lynch JM. Origin, nature and biological activity of aliphatic substances and growth hormones found in soil. In: Soil Organic Matter and Biological Activity. Eds. Vaughan D and Malcom RE. Martinus Nijhoff/Dr. W. Junk Publishers. Dordrecht, Boston , Lancaster. 1985. pp 151-174

4. Frankenberger WT Jr., Brunner W. Methods of detection of auxin-indole acetic acid in soil by high performance liquid chromatography. Soil Soc Am J 47: 237-241, 1983.

5. Farah Ahmad., Iqbal Ahmad., Mohd Saghir Khan. Indole Acetic Acid Production by the Indigenous Isolates of Azotobacter and Fluorescent Pseudomonas in the Presence and Absence of Tryptophan. Turk Journal of Biology 29 (2005) 29-34.

6. FAO: Application of Nitrogen-Fixing Systems in Soil Improvement and Management. Food and Agriculture Organization of the United Nations. FAO Soils Bulletin 49, Rome (1982).

7. Vessey, J.K. 2003. Plant growth promoting rhizobacteria as biofertilizers. Plant soil. 255:517-586.

8. Garg, S.K., Bhatnagar, A., Kalla, A., Narula, N., 2001. In vitro nitrogen fixation, phosphate solubilization, survival and nutrient release by Azotobacter strains in an aquatic system. Bioresearch Technology 80, 101-109.

9. Kumar, V., Singh, K.P., 2001. Enriching vermicompost by nitrogen fixing and phosphate solubilizing bacteria. Bioresource Technology 76, 173-175.

10. Clementi, F., 1997. Alginate production by Azotobacter vinelandii. Critical Review in Biotechnology 4, 327361.

11. Vikram Patil. Production of Indole Acetic Acid by Azotobacter sp. Recent Research in Science and Technology 2011, 3(12): 14-16.

12. Madhuri M. Sahasrabudhe. Screening of rhizobia for indole acetic acid production., Annals of Biological Research, 2011, 2 (4) :460-468.

13. Farah ahmad, Iqbal ahmad, Mohd saghir khan. Indole acetic acid production by the indigenous isolates of Azotobacter and fluorescent Pseudomonas in the presence and absence of tryptophan, Turkey journal of Biology, 2005, 29 (2005):29-34.

14. Sivasankari, B. and Daniel, T. 2010. A study on isolation and characterization of PGR producing microorganisms from vermicompost. J.of Environment and Ecology. 28(44):2509-2510.

15. Ahamed, F., Ahamed, L. and Khan, M.S. 2005. Indole acetic acid production by the indigenous isolates of Azotobacter and fluorescent Pseudomonas in presence and absence of tryptophan. Turk J.Biol. 29:29-34.

16. Pattern and Glick, 2002

17. Barazani OZ, Friedman J. Is IAA the major root growth factor secreted from plant-growth-mediating bacteria? J Chem Ecol 25: 2397- 2406, 1999.

18. Sarwar M, Frankenberger WT Jr. Tryptophan dependent biosynthesis of auxins in soil. Plant and Soil 160: 97104, 1994.

19. Sadaf Shahab, Nuzhat Ahmed and Nasreen S.Khan. indole acetic acid production and enhanced plant growth promotion by indigenous PSBs. African journal of Agricultural research vol. 4 (11),pp 1312-1316, November, 2009. 